\title{
Branding Online News Providers: Brand Personality and the Image Congruence Effect
}

\author{
Brian T Parker \\ Correspondence: Brian T Parker, Assistant Professor, School of Communication, Florida State University, United States
}

Received: August 29, 2014 Accepted: September 9, 2014 Available online: September 28, 2014

doi:10.11114/smc.v2i2.502 URL: http://dx.doi.org/10.11114/smc.v2i2.502

\begin{abstract}
This study examined online news brand personality and conducted an empirical test of the image congruence hypothesis. A survey of 271 respondents gauged the brand personality of three online news brands (i.e., Google News, Yahoo! News, and CNN online) and respondents' self-image perceptions to determine if self-brand image congruence relates to predispositions to behave in a favorable manner toward this brand type. Congruence scores served as indicators of the difference between respondents' actual and ideal self-image and each brand's personality assessed on five factors: sincerity, competence, sophistication, excitement, and ruggedness. Self-brand personality distance scores served as independent variables in stepwise regressions with brand attitude and likelihood of visiting/using the online brand as the dependent variables. Significant results, although not accounting for much variance, support the proposed relations, indicating that brand personality and image congruence are worthwhile topics of investigation for online news brands.
\end{abstract}

Keywords: news brands, online news, brand personality, image congruence, self-congruity

\section{Introduction}

For online news providers, increasing viewer loyalty and familiarity is paramount in today's expanding digital media landscape. Continuous technology growth keeps the media environment in a state of constant flux with increasing choices for consumers of online news, yet an extremely fragmented audience for an advertiser demanding precision demographic ratings. With the numerous choices available from webpages, smartphone applications, micro-blogging (e.g., Twitter), as well as traditional media, strategic differentiation (i.e., branding) of online news providers (e.g., Yahoo! News) and branding theories are important to consider for building a loyal audience base that attracts top-tier advertisers.

Media marketing reflects theories, methods, and techniques used by commercial marketing to promote identity and value, evident by the diffusion of branding strategies in the media industry (Chan-Olmsted \& Jung, 2001). For example, McDowell (1998) applied the brand equity construct as a measure of media brand value, illustrating a relationship between program rating and brand value. Brand equity generated by successful network television series has a positive relationship with spin-off longevity and parent brand advancement (Landers, 2004). Similarly, studies illustrate factors (e.g., parent brand attitude, familiarity, and portfolio quality) that influence attitudes toward media brand extensions (Chang \& Chan-Olmsted, 2010; Dacin \& Smith, 1994). Chan-Olmsted \& Kim (2002) documented differences on brand image perceptions between cable and public television brands, particularly on perceptions of brand quality and trustworthiness.

Branding is ultimately about cultivating a strong, favorable image that differentiates the brand in consumer memory, and generates goodwill toward the company (brand owner), product/service offerings, and future marketing actions. Brand image, that is, perceptions individuals have of a brand, plays an important role in brand preference and choice by influencing consumers' predispositions and attraction toward the brand (Aaker, 1996; Keller, 1993). Individuals often use and possess brands because of the personality or human characteristics associated with the brand image (e.g., sophisticated or athletic), rather than the actual product/service function the brand represents (Aaker, 1996; Graeff, 1996; Grubb \& Grathwhohl, 1967; Keller, 1993; Underwood, 2001). This aspect of a brand image, referred to as a brand personality, is a strong point of brand differentiation, and plays a critical role in the 'for me' choice, or 'I see myself in that brand' choice (Plummer, 2000, p. 81).

Self-congruity theory (Sirgy, $1982 \&$ 1986) explains that brand and product choice is often a function of image congruence, a mental comparison that consumers make in regards to the similarity or dissimilarity of a brand's image or 
personality and their own self-image. Evidence shows that image congruence plays a significant role in brand choice for a variety of different product categories, such as automobiles, fashion, travel destinations, and universities, illustrating the importance of positioning toward the image most desired by the target audience. The purpose of the present study was to examine the brand personality of online news brands, and test the hypothesis that image congruence between viewer self and brand personality plays a role in viewer selection of online news brands.

\subsection{The Image Congruence Hypothesis}

The image congruence hypothesis purports that as the similarity (i.e., congruence) between an individual's self-image and a brand's image increases, so should the favorability of brand attitudes (Dolich, 1969; Gould, 1991; Sirgy, 1982 \& 1986). Theoretically, this is important because brand attitudes (i.e., predispositions to respond in a consistently favorable or unfavorable manner toward a brand name, symbol, logo, or other brand identifier), are a key indicator of an individual's behavior toward the brand (Fishbein \& Ajzen, 1975; Mitchell \& Olson, 1981; Keller, 1993; Spears \& Singh, 2004). Numerous studies support this hypothesis, documenting the image congruence effect on brand attitudes, as well as variables such as purchase intentions, brand preference, choice, and loyalty (Birdwell, 1968; Erickson, 1996; Grubb \& Grathwhohl, 1967; Graeff, 1996; Malhotra, 1981; Ross, 1971; Sirgy, 1982).

Self-brand congruity, the degree of congruence between self and brand image, is a latent variable observable by employing psychometric techniques to measure individuals' self and brand image perceptions. The conceptualization of self-image derives from psychology literature, while brand image is a marketing construct typically defined as brand user-imagery or brand personality, two related constructs that refer to symbolic, human-based aspects of a brand image (Aaker, 1996; Hogg, Alastair \& Kelling, 2000). Because self and brand image perceptions are central to self-brand congruity research, it is important to expound their conceptualizations.

\subsection{Self-Image}

Simply put, self-image is the manner in which one perceives her/himself to be as an individual (Grubb \& Grathwhohl, 1967; Graff, 1996). Self-perceptions change from situation to situation, making self-image a multidimensional construct that is comprised of two major dimensions: the "actual-self" and the "ideal-self" (Aaker, 1999; Gould, 1991; Graeff, 1996; Sirgy, 1982 \& 1986). The actual self (i.e., "me as I am”), are beliefs about who we are right now, and the ideal self (i.e., "the good me"), are beliefs of an imagined ideal, the image of the self as one desires to be (Grubb \& Grathwhohl, 1967; Rogers, 1959; Sirgy, 1982).

Self-image is an important construct because social psychologists theorize the protection of the self is the basis for many motivated human behaviors (Franken, 1994; Ziegler \& Hjelle, 1992). According to psychologist Carl Rogers (1959), every individual has a motivational drive propelled by an 'actualizing tendency' that serves the purpose to develop all abilities in ways that maintain an integrated self-image. Possessions, including brands and products, become extensions of the 'self', facilitating the drive toward self-preservation (Belk, 1988; McCraken, 1986; Zinkham \& Hong, 1991).

\subsection{Brand Image and Personality}

Brand image is an overall perception, a mental representation about a brand indicated by informational associations stored in consumer memory (Aaker, 1996; Keller, 1993). Salient brand associations, linked to a brand name in memory, are what consumers think about when characterizing a brand's image (Batra et al., 1996; Keller, 1993). There are different types of brand image associations that relate to underlying consumption motivations that transpose to the brand image: functional needs (i.e., desire for problem removal), experiential/sensory needs (i.e., what it feels like to use a product), and symbolic needs (i.e., social approval and personal expression) (Park, Jaworski \& MacInnis, 1986).

It is important to distinguish between brand image association types because the self-brand congruence phenomenon is a function of symbolic consumption motivations. Functional and experiential brand associations link to product related attributes (i.e., physical product characteristics and features needed for performing the product function) and non-product related (e.g., price and packaging) attributes (Keller, 1993). In contrast, symbolic brand associations relate to non-product attributes, such as different values (e.g., health) or personality traits (e.g., rugged or extroverted), as discussed become an enduring part of the brand's overall image (Aaker, 1997; Patterson, 1999; Plummer, 2000; Solomon, 1983).

Brand personality is human characteristics or traits associated with a brand (Aaker, 1997). For example, respondents characterized the brand personality of Oil of Olay as "upscale" and "aspirational," while Absolut vodka's brand personality has been characterized as "cool," "hip," and "contemporary" (Aaker, 1997; Plummer, 2000). Personality trait associations create a brand image with person like qualities that consumers respond to in a similar manner as one would respond to another person with similar traits. Research supports the notion that consumers have a tendency to imbue brands with human characteristics, thinking of them as if they are more than inanimate objects. Brand personality 
is a viable unit of empirical observation, and an enduring brand asset, which when well-developed, can increase brand awareness and loyalty, brand differentiation, and enhance the favorability toward a brand (Phau \& Lau, 2001; Plummer, 2000).

Aaker (1997) developed a brand personality model and set of scales based on a comprehensive, five-factor classification of human personality advocated by psychologists. This model and corresponding Brand Personality Scales (BPS) measure five-personality dimensions derived from a factor analysis of 114 human personality traits. The factor analysis resulted in a robust, five-factor model of brand personality: Sincerity, Excitement, Competence, Sophistication, and Ruggedness. Aaker's (1997) framework is the dominant paradigm in brand personality research, and evidence illustrates the BPS are reliable and generalizable across different brands and product categories.

The 'Sincerity' dimension captures the idea of a warm and accepting brand personality that is down-to-earth, honest, wholesome, and cheerful. A brand personality high on 'excitement,' is sociable, energetic, daring, while also imaginative and up to date. A 'competent' brand personality is responsible, dependable, and secure, intelligent, and successful. According to Aaker (1997), the brand personality dimensions 'Sophistication' and 'Ruggedness' differ from any known major dimension of human personality and the author suggests that these two dimensions may relate to or tap into brand personality dimensions that individuals' desire but do not necessarily have. A 'sophisticated' personality is upper class and charming, whereas a 'rugged' typology has outdoorsy and tough personality traits.

\subsection{Research Agenda and Hypotheses}

This study examined the image congruence hypothesis in the context of online news brands, specifically to determine if self-brand personality congruence has a significant relationship with individuals' tendency to use the news source. Overall, the research agenda was to explore the relationship among the self-image (i.e., actual and ideal) of the consumer, the consumer's perceptions of online news provider brand personality, and behavioral indicators, including attitude-toward-the online news brand and intention (i.e., likelihood) of visiting or using each brand. Affirmative evidence of an image congruence effect would indicate that brand evaluations and the probability that a potential audience member will behave in a positive manner toward a brand would increase as the similarity (i.e., congruence) between an online news brand's personality and viewers' self-image increases. Hence, this study addressed the following hypotheses.

HO$_{1}$ : There will be a significant, positive relationship between online news brand attitude and the likelihood of visiting/using online news brands.

$\mathbf{H O}_{2}$ : There will be a significant, positive relationship between self-brand personality congruity and online news brand attitude.

$\mathbf{H O}_{2}$ : There will be a significant, positive relationship between self-brand personality congruity and the likelihood of visiting/using online news brands.

Moreover, self-brand image congruence influences consumer brand attitudes through mediating drives of two motivations: self-esteem and self-consistency (Sirgy, 1986). At times, individuals match brand image with their 'actual' self-image, and other instances match brand image with 'ideal' self-image perceptions (Graeff, 1996; Landon, 1974). From a self-esteem perspective, individuals are motivated to approach positively valued 'ideal' image brands that help maintain or enhance self-image perceptions. A self-consistency perspective, on the other hand, suggests that a consumer will be attracted toward a brand with an image consistent with 'actual' self-image perceptions. Therefore, the second major goal of this study was to determine whether online news brands' personality appeals more to viewers' ideal-self (i.e., self-esteem needs) or actual-self (i.e., self-consistency needs) when an image congruence effect is evident, as stated by the following research question.

$\mathbf{R Q}_{1}$ : When a significant relationship between online news brand attitude and / or likelihood of visiting an online news brand with self-brand congruence is evident, does 'actual' or 'ideal' self-brand congruence, show a stronger relationship with the outcome variable?

\section{Method}

The study design employed a digital survey executed with a web-based questionnaire developed using Qualtrics Research Suite, a service that provides design and analysis features for conducting digital research. Three online news brands (i.e., Goggle News, Yahoo! News, and CNN.com) selected from preliminary research, served as the units of analysis. Respondents in both the preliminary research and primary survey were undergraduate college students recruited from courses at a large, southeastern U.S. university.

\subsection{Online News Brand Selection}

A preliminary survey generated a list of online news providers frequently used by a sample of eighty-six $(\mathrm{N}=86)$ 
college students. A researcher asked respondents if they keep up with current news events using any online source, and if so, to write down the top-three news brands they visit on a regular basis. The top ten most frequently mentioned online news sources from this procedure were (in descending order) Google News, Yahoo! News, CNN, MSNBC, The Huffington Post, Twitter, The New York Times, BBC News, Fox News, and Associated Press. From this list, the researcher selected the top three brands for analysis. Brand names, rather than logos or other insignia, were the focal point of analysis because they are the part of a brand apart from other symbols that is the primary indictor of brand value (Cobb-Walgreen et al., 1995).

\subsection{Measures}

Prior to brand exposure, the questionnaire collected basic demographic variables (i.e., gender, ethnicity, and age) and assessed respondent's actual and ideal self-image perceptions with the brand personality scales (BPS) described in the forthcoming section. A single-item (i.e., $1=$ yes or $0=$ no) brand familiarity rating allowed for the exclusion of respondents not familiar with a brand. For familiar brands, the questionnaire presented respondents with measures for online news brand attitude and likelihood to visit/use the news brand.

The brand attitude measure was an index of a three-item (i.e., favorable/unfavorable, good/bad, and likeable/unlikable), seven-point semantic differential scale (Mackenzie, Lutz \& Park, 1989). The measurement of one's 'likelihood to visit' the online news brand, used a five-point Likert scale $(1=$ I would definitely not visit to $5=$ I definitely would visit $)$ in response to the question, "What is the likelihood that you will visit/use [brand x's] the next time you go online to check the latest news or current events?"

The operationalization of self-brand congruity involves using a set of image scales for respondents to assess their own self-image and a brand's image, and then using calculations to determine the difference or distance between image measures. Distance scores, the focal point of analysis, represent the congruence between the two image perceptions (Birdwell, 1968; Dolich, 1969; Gould, 1991; Graeff, 1996; Grubb \& Grathwhohl, 1967; Sirgy, 1986). The present operationalization of self-brand personality congruity employed Aaker's (1997) fifteen-item BPS to assess both brand personality and self-image perceptions to avoid the methodological flaw of using separate image measures (Bellenger, Steinberg, \& Stanton, 1976).

There are two primary reasons to employ BPS scales in self-brand congruity research. First, the basis of the BPS scales derive from research employing techniques outline by Malhotra (1981), who developed a process of scale development for measuring self, person, and product concepts, which is commonly applied in congruity research. Second, researchers have validated the BPS scales in self-brand congruity research for measuring consumers' self-image, in which respondents rated themselves on the BPS traits, used to determine brand image congruence (Aaker, 1999).

BPS indicators for each factor included four for 'sincerity' (down-to-earth, honest, wholesome, and cheerful), four for 'excitement' (daring, spirited, imaginative, and up-to-date), three for 'competence' (reliable, intelligent, and successful), two for 'sophisticated' (upper class and charming), and two for 'ruggedness' (outdoorsy and tough).

For self-perceptions, instructions asked respondents to "think about how you see yourself from two different points of view: (1) how you actually see yourself and (2) how you would ideally like to be." Using a 5-point Likert scale ("not at all descriptive' to 'extremely descriptive') respondents indicated how well each BPS characteristic described their actual self, that is, "the sort of person you think you are, or the way in which you actually see yourself," and their ideal self, that is, "the sort of person you would ideally like to be."

For brand personality, the questionnaire instructed respondents to think of the brands as if each were a person. After asking respondents to image the type of person a brand is, they were next instructed to describe the brand's personality by indicating how descriptive each BPS indicator was of the brand using the same 5-point Likert scale ('not at all descriptive' to 'extremely descriptive') used for self-perceptions.

$$
\Sigma=\left(\mathrm{P}_{\mathrm{ij}}-\mathrm{S}_{\mathrm{ij}}\right)^{2} \& \sum=\left(P_{i j}-I_{i j}\right)^{2}
$$

$$
\begin{aligned}
& \text { Where } \\
& \mathrm{P}_{i j}=\text { brand image perception }\left({ }_{i}\right) \text { of individual }\left({ }_{j}\right) \\
& \mathrm{S}_{i j}=\text { actual self-image }\left({ }_{i}\right) \text { of individual }\left({ }_{j}\right) \\
& \mathrm{I}_{i j}=\text { ideal self-image }\left({ }_{i}\right) \text { of individual }\left({ }_{j}\right)
\end{aligned}
$$

Calculations using the distance-squared (d-score) equation (1), represents the congruence between respondents' self (actual and ideal) and brand personality scores. Lower d-scores represent less distance between brand and self-image perceptions, hence higher self-brand congruity. Ten self-brand personality congruity scores were calculated for analysis, one for each brand personality factor with both self-image measurements (i.e., actual and ideal). Hence, rather than looking at a composite brand personality score, this study examined self-brand congruence for each personality trait. 


\section{Results}

Two hundred seventy one $(n=271)$ questionnaires were collected for analysis from a sample of upper level college students. The final sample skewed toward females, representing 62 percent of respondents, and was multi-ethnic including African-American, Hispanic, Native American, White, and few ethnicities recorded as other. Average respondent age was twenty.

\subsection{Descriptive Statistics for Study Variables}

As expected, each online news brand had high levels of familiarity. Google News rated highest on both the brand attitude $(M=5.42)$ and likelihood to visit $(M=3.75)$ measures, followed by Yahoo! News and CNN (Table 1$)$. There was a positive correlation, significant at the .01 level, between news brand attitude and the likelihood of visiting each brand: Google News $(r=.75)$, Yahoo! News $(r=.80)$, and CNN $(r=.68)$. Cronbach's Alpha reliability coefficients showed high consistency (ranged between .86 and .93) for the brand attitude indices for each news brand. The strong, positive correlations between brand attitude and likelihood of visiting illustrate the expected relationship between these two variables, providing evidence in support of the first hypothesis.

Table 1. Online News Provider Brand Attitude, Likelihood to Visit, and Correlations (with Standard Deviations in Parentheses)

\begin{tabular}{llll}
\hline & \multicolumn{2}{l}{ Behavioral Indicator Variables } & \\
\cline { 2 - 3 } Online News Brand & Brand Attitude & Likelihood of Visiting & Correlation \\
\hline Google News & $5.42(1.37)$ & $3.75(1.05)$ & $.75^{* *}$ \\
Yahoo! News & $4.97(1.67)$ & $3.56(1.30)$ & $.80^{* *}$ \\
CNN & $4.54(1.52)$ & $2.89(1.09)$ & $.68^{* *}$ \\
\hline
\end{tabular}

Note. $N$ 's range from 256 to 271 due to occasional missing data.

$* * p<.05$.

\subsection{Brand Personality and Self-Image}

Analysis for each news brand and definition of respondent self-image (i.e., actual and ideal) included the mean for each BPS dimension and assigned a dominant personality trait based on the two highest rated BPS dimensions. Each brand personality dimension represents an index of its individual indicators for that BPS facet (e.g., competence $=$ reliable, intelligent, and successful). Table 2 shows each brand's BPS mean index scores and respondent self-image definition.

Review of the BPS literature (i.e., Aaker, 1997), for profiles of the personality types provides more detail of each brand's personality. Google News rated highest on 'sophistication' and 'competence' dimensions, characterizing an upper class and charming personality, considered dependable and secure. Yahoo! News rated highest on the 'sophistication' and 'excitement' dimensions, capturing a charming personality that is sociable, energetic, and active. In comparison, the brand $\mathrm{CNN}$, rated highest on the 'sincerity' and 'competence' dimensions, characterizing a warm and caring personality that is also dependable and secure. Notably, each news provider had different brand personalities, illustrating that online news brands have unique images that can serve as a point of differentiation that goes beyond the functional service or content offerings.

Table 2. Online News Brand Personality and Respondent Self-Image (with Standard Deviations in Parentheses)

\begin{tabular}{|c|c|c|c|c|c|}
\hline \multirow[b]{2}{*}{$\begin{array}{l}\text { Brand } \\
\text { Dimension }\end{array}$} & \multicolumn{3}{|l|}{ News Brand } & \multicolumn{2}{|c|}{ Respondent Self-Image } \\
\hline & $\begin{array}{l}\text { Goggle } \\
\text { News }\end{array}$ & Yahoo! News & $\mathrm{CNN}$ & $\begin{array}{l}\text { Actual } \\
\text { Self-Image }\end{array}$ & $\begin{array}{l}\text { Ideal } \\
\text { Self-Image }\end{array}$ \\
\hline Sincerity & $3.02(0.85)$ & $2.35(0.77)$ & $3.46(0.83)$ & $3.77(0.62)$ & $4.36(0.62)$ \\
\hline Excitement & $2.92(0.82)$ & $3.23(0.88)$ & $2.50(0.86)$ & $3.56(0.67)$ & $4.25(0.65)$ \\
\hline Competence & $3.86(0.90)$ & $2.63(0.92)$ & $3.28(0.90)$ & $4.04(0.65)$ & $4.79(0.48)$ \\
\hline Sophistication & $3.97(0.86)$ & $3.30(0.99)$ & $2.65(0.87)$ & $3.40(0.85)$ & $4.35(0.77)$ \\
\hline Ruggedness & $1.76(0.89)$ & $2.27(1.08)$ & $2.42(1.21)$ & $3.03(1.12)$ & $3.89(1.02)$ \\
\hline
\end{tabular}

Note. N's range from 256 to 271 due to occasional missing data.

\subsection{Self-Brand Congruity Analysis}

A series of stepwise multiple regression analyses addressed hypotheses two and three by exploring the relationship between self-brand personality congruity scores, brand attitude, and likelihood to visit Google News, Yahoo! News, and $\mathrm{CNN}$ online. For each analysis, there were ten independent variables, each a d-score measure representing the distance (i.e., congruence) between each of the five-brand personality dimensions and respondents' actual and ideal self-image perceptions on the same measures (Table 3). For hypothesis two, brand attitude served as the dependent variable and for hypotheses three, likelihood of visiting each news brand was the dependent measure. 
Table 3. Independent Variables: Self-Brand Personality Congruities

\begin{tabular}{ll}
\hline Self-Brand Personality Congruities & \\
\hline Actual Self-Brand Personality Congruity & Ideal Self-Brand Personality Congruity \\
\hline Actual Self (SN) - Brand Personality (SN) & Actual Self (SN) - Brand Personality (SN) \\
Actual Self (EX) - Brand Personality (EX) & Actual Self (EX) - Brand Personality (EX) \\
Actual Self (CO) - Brand Personality (CO) & Actual Self (CO) - Brand Personality (CO) \\
Actual Self ( SP) - Brand Personality (SP) & Actual Self ( SP) - Brand Personality (SP) \\
Actual Self (RU) - Brand Personality (RU) & Actual Self (RU) - Brand Personality (RU) \\
\hline
\end{tabular}

Note. Sincerity (SN), Excitement (EX), Competence (CO), Sophistication (SP), Ruggedness (RU)

Procedures followed the approach to multivariate model building outlined by Hair et al. (1998). R-square ( $\left.\mathrm{R}^{2}\right)$ and beta weight statistics indicated which independent variables (i.e., self-brand congruities) accounted for the greatest variance on dependent measures. In the employed forward selection regression procedures, the first variable entered into a final model has the strongest relationship with the dependent measure, and subsequent steps added significant variables until none improved the model. Furthermore, it was expected that significant regression coefficients for self-brand congruity d-scores would be negative because the closer the distance, the more favorable attitudes and intentions toward the brand, according to the image congruence hypothesis.

\subsection{Online News Provider Brand Attitude}

Tables 4 thru 6 present the brand attitude-regression models for each of the three online news brands. For attitude-toward-Goggle News (Table 4), the stepwise procedures resulted in a two-model solution with actual self 'sincerity' (SN) congruity and ideal self 'competence' (CO) congruities, accounting for about 20 percent of the variance $\left(\mathrm{R}^{2}=.200\right)$ on the dependent measure. For Yahoo! News (Table 5), analysis resulted in a three-model solution that included ideal self 'sincerity' (SN), actual self 'sophistication' (SP), and actual self 'excitement' congruities, accounting for 17 percent of variance $\left(\mathrm{R}^{2}=.175\right)$ on the attitude measure. Results for CNN (Table 6) also produced a two variable solution that included actual self 'competence' (CO) and actual self 'sophistication', accounting for 21 percent of explained variance $\left(\mathrm{R}^{2}=.214\right)$ on the dependent. Albeit not conclusive, these results support the second hypothesis, showing that self-brand congruence positively relates to brand attitude in the context of online news brands.

Table 4. Stepwise Regression of Self-Brand Personality Congruities on Google News Brand Attitude

\begin{tabular}{|c|c|c|c|c|c|c|}
\hline \multirow[b]{2}{*}{ Variable } & \multicolumn{3}{|c|}{ Model 1} & \multicolumn{3}{|c|}{ Model 2} \\
\hline & $B$ & $S E B$ & $\beta$ & $B$ & $S E B$ & $\beta$ \\
\hline Actual self (SN) - Google News (SN) & -.174 & .042 & $-.257 * *$ & -.132 & .043 & $-.196^{* *}$ \\
\hline Ideal self $(\mathrm{CO})$ - Google News $(\mathrm{CO})$ & & & & -.101 & .034 & $-.194 *$ \\
\hline$R^{2}$ & & 0.166 & & & 0.200 & \\
\hline$F$ for change in $R^{2}$ & & & & & $9.06^{*}$ & \\
\hline
\end{tabular}
$* p<.05 . * * p<.01$.

Table 5. Stepwise Regression of Self-Brand Personality Congruities on Yahoo! News Brand Attitude

\begin{tabular}{|c|c|c|c|c|c|c|c|c|c|}
\hline \multirow[b]{2}{*}{ Variable } & \multicolumn{3}{|c|}{ Model 1} & \multicolumn{3}{|c|}{ Model 2} & \multicolumn{3}{|c|}{ Model 3} \\
\hline & $B$ & $S E B$ & $\beta$ & $B$ & $S E B$ & $\beta$ & $B$ & $S E B$ & $B$ \\
\hline $\begin{array}{l}\text { Ideal self }(\mathrm{SN}) \text { - Yahoo! } \\
\text { News }(\mathrm{SN})\end{array}$ & -.134 & .026 & $-.318 * *$ & -.121 & .025 & $-.286 * *$ & -.104 & .026 & $-.246 * *$ \\
\hline $\begin{array}{l}\text { Actual self (SP) - } \\
\text { Yahoo! News (SP) }\end{array}$ & & & & -.135 & .039 & $-.208 *$ & -.123 & .039 & $-.189 *$ \\
\hline $\begin{array}{l}\text { Actual self (EX) - } \\
\text { Yahoo! News (EX) }\end{array}$ & & & & & & & -.181 & .059 & $-.186^{*}$ \\
\hline $\begin{array}{l}R^{2} \\
F \text { for change in } R^{2}\end{array}$ & & 0.101 & & & $\begin{array}{r}0.143 \\
11.96^{*} \\
\end{array}$ & & & $\begin{array}{l}0.175 \\
9.42 * \\
\end{array}$ & \\
\hline
\end{tabular}
$* p<.05 . * * p<.01$.

Table 6. Stepwise Regression of Self-Brand Personality Congruities on CNN Online Brand Attitude

\begin{tabular}{|c|c|c|c|c|c|c|}
\hline \multirow[b]{2}{*}{ Variable } & \multicolumn{3}{|c|}{ Model 1} & \multicolumn{3}{|c|}{ Model 2} \\
\hline & $B$ & $S E B$ & $\beta$ & $B$ & $S E B$ & $\beta$ \\
\hline Actual self $(\mathrm{CO})-\mathrm{CNN}(\mathrm{CO})$ & -.246 & .038 & $-.415 * *$ & -.213 & .039 & $-.359 * *$ \\
\hline Actual self (SP) - CNN (SP) & & & & -.096 & .038 & $-.168 *$ \\
\hline$R^{2}$ & & 0.197 & & & 0.214 & \\
\hline$F$ for change in $R^{2}$ & & & & & $6.40 *$ & \\
\hline
\end{tabular}

$* p<.05 . * * p<.01$. 


\subsection{Likelihood of Visiting Online News Provider}

Regression analyses on likelihood of visiting each online news brand with the self-brand personality congruity measures (Tables 7 - 9) addressed the third hypothesis. For Google News (Table 7), the final model included two variables (i.e., ideal self 'competence' (CO) and ideal self 'sincerity' (SN) congruities) that explained nearly 21 percent of the variance $\left(\mathrm{R}^{2}=.207\right)$ on the dependent. For Yahoo! News (Table 8$)$, the procedures resulted in a three-variable model (i.e., ideal self 'excitement' (EX), ideal self 'sincerity' (SN), and actual self 'sophistication' (SP) congruities), also accounting for about 20 percent variance $\left(\mathrm{R}^{2}=.198\right)$ on the dependent. Analysis also produced a three variable model for CNN (Table 9) that included the ideal self 'competence' (CO), ideal self 'excitement' (EX), and the actual self 'sophistication' (SP) congruities, accounting for about 12 percent of the dependent measure variance $\left(\mathrm{R}^{2}=.118\right)$. Self-brand congruence illustrated a positive relationship with the likelihood of visiting each online news brand, supporting the third research hypothesis.

Table 7. Stepwise Regression of Self-Brand Personality Congruities on Likelihood of Visiting Google News

\begin{tabular}{|c|c|c|c|c|c|c|}
\hline \multirow[b]{2}{*}{ Variable } & \multicolumn{3}{|c|}{ Model 1} & \multicolumn{3}{|c|}{ Model 2} \\
\hline & $B$ & $S E B$ & $\beta$ & $B$ & $S E B$ & $\beta$ \\
\hline Ideal self (CO) - Google News (CO) & -.124 & .024 & $-.301 * *$ & -.104 & .026 & $-.252 * *$ \\
\hline Ideal self (SN) - Google News (SN) & & & & -.049 & .022 & $-.138 *$ \\
\hline$R^{2}$ & & 0.190 & & & 0.207 & \\
\hline$F$ for change in $R^{2}$ & & & & & $4.95 *$ & \\
\hline
\end{tabular}

Table 8. Stepwise Regression of Self-Brand Personality Congruities on Likelihood of Visiting Yahoo! News

\begin{tabular}{|c|c|c|c|c|c|c|c|c|c|c|}
\hline \multirow[b]{2}{*}{ Variable } & & \multicolumn{3}{|c|}{ Model 1} & \multicolumn{3}{|c|}{ Model 2} & \multicolumn{3}{|c|}{ Model 3} \\
\hline & & $B$ & $S E B$ & $\beta$ & $B$ & $S E B$ & $\beta$ & $B$ & $S E B$ & $\beta$ \\
\hline $\begin{array}{l}\text { Ideal self }(\mathrm{EX}) \\
\text { Yahoo! News }(\mathrm{EX})\end{array}$ & - & -.165 & .029 & $-.327 * *$ & -.120 & .031 & $-.238 * *$ & -.110 & .030 & $-.218 * *$ \\
\hline $\begin{array}{l}\text { Ideal self }(\mathrm{SN}) \\
\text { Yahoo! News }(\mathrm{SN})\end{array}$ & - & & & & -.079 & .020 & $-.236 * *$ & -.064 & .021 & $-.190 *$ \\
\hline $\begin{array}{l}\text { Actual self (SP) } \\
\text { Yahoo! News (SP) }\end{array}$ & - & & & & & & & -.040 & .015 & $-.156^{*}$ \\
\hline$R^{2}$ & & & 0.154 & & & 0.176 & & & 0.198 & \\
\hline$F$ for change in $R^{2}$ & & & & & & $6.86^{*}$ & & & $7.22 *$ & \\
\hline
\end{tabular}

$* p<.05 . * * p<.01$.

Table 9. Stepwise Regression of Self-Brand Personality Congruities on Likelihood of Visiting CNN Online

\begin{tabular}{|c|c|c|c|c|c|c|c|c|c|}
\hline \multirow[b]{2}{*}{ Variable } & \multicolumn{3}{|c|}{ Model 1} & \multicolumn{3}{|c|}{ Model 2} & \multicolumn{3}{|c|}{ Model 3} \\
\hline & $B$ & $S E B$ & $\beta$ & $B$ & $S E B$ & $\beta$ & $B$ & $S E B$ & $\beta$ \\
\hline $\begin{array}{l}\text { Ideal self }(\mathrm{CO})-\mathrm{CNN} \\
(\mathrm{CO})\end{array}$ & -.085 & .019 & $-.275^{* *}$ & -.066 & .020 & $-.212^{*}$ & -.054 & .021 & $-.176^{*}$ \\
\hline $\begin{array}{l}\text { Ideal self }(\mathrm{EX})-\mathrm{CNN} \\
(\mathrm{EX})\end{array}$ & & & & -.050 & .018 & $-.179 *$ & -.043 & .019 & $-.155^{*}$ \\
\hline $\begin{array}{l}\text { Actual self }(\mathrm{SP})-\mathrm{CNN} \\
(\mathrm{SP})\end{array}$ & & & & & & & -.053 & .027 & $-.132 *$ \\
\hline$R^{2}$ & & 0.075 & & & 0.104 & & & 0.118 & \\
\hline$F$ for change in $R^{2}$ & & & & & $7.35^{*}$ & & & $3.90 *$ & \\
\hline
\end{tabular}

$* p<.05 . * * p<.01$.

\section{Discussion}

Brands communicate information other than product or service functions, which often plays a central role in the 
consumer decision process. This study examined the brand personality and empirically tested the image congruence hypothesis for online news brands. Respondents perceived unique, dominant personality traits in the analyzed brands, illustrating important points of brand image differentiation. Overall, respondents perceived Google News as sophisticated and competent, Yahoo! News also as sophisticated, yet exciting, and CNN as sincere and competent. Albeit these are generalized perceptions, brand personality analysis illustrates online news brands occupy unique brand image positions that could facilitate news source choice.

Significant, but not accounting for a large percentage of explained variance, self-brand personality congruity related to online news brand attitude and the likelihood of visiting. While not conclusive, these findings support the proposed hypotheses, and provided evidence that audience attitudes and behavioral intentions toward online news brands are partly a function of brand image congruence. The brand personality dimensions producing significant results on (1) brand attitudes were actual and ideal measures of 'sincerity' and 'competence,' and actual measures of 'sophistication' and 'excitement,' and (2) on likelihood to visit, were actual and ideal measures 'competence,' 'sincerity,' 'excitement,' and actual measures of 'sophistication.'

In general, image congruence occurred most often for 'sincerity,' and 'competence' brand personality factors, while 'ruggedness,' a personality trait defined as outdoorsy and tough, was not a significant factor throughout the analyses. These personality traits may characterize aspects important to online news brands in general. While suggested by the evidence, analysis of a larger variety of brands is required to address this assumption and generalize the present findings to the online news brand genre.

Of the ten self-brand congruities selected for the multiple regressions, both actual and ideal distance scores entered into the final models, yet differences were evident for the two dependent measures. For brand attitude, five of the seven significant self-brand personality congruities were actual self-image. This suggests that self-consistency of one's self-perceptions may play a role in attitude formation toward online news brands. The results were nearly reverse on the likelihood to visit / use an online brand measure: of the eight significant self-brand congruities, six were ideal-based. This is an important finding because ideal self-image congruities are a function of individuals' self-esteem needs, and tapping this important human motivator could facilitate brand choice.

\subsection{Implications}

Although based on a non-random sample of university students, the present results illustrate the implications of this type of research. Overall, news brands, when working toward building favorable brand attitudes, typically a long-term and persistent objective, should position image strategies toward audience members' actual self-image or self-consistency needs. Whereas when developing short-term brand strategies for increasing online traffic, or increasing the likelihood of brand use, news brands should focus more on ideal self-image positioning toward personality traits where congruence is a significant factor.

Respondents perceived both Google News and Yahoo! News as sophisticated, charming brands - the point of differentiation between the two brands is that Google has a dependable personality, while Yahoo! News was more of a sociable and energetic personality. Nonetheless, based on the self-congruity analyses, both of these brands should position toward 'sincerity' by showing to be a honest, cheerful, and wholesome brand given that this trait was significant with ideal self-image on both the brand attitude and likelihood to use measures. Whereas CNN had a sincere and competent brand personality, one that is distinct from the other two brands. For CNN, self-congruity analysis suggests to build favorable brand attitudes toward this audience, emphasis should be placed on competence, while positioning the brand as more sophisticated and charming. In addition, for the CNN brand, likelihood to visit increased as congruence with the ideal excitement trait increased, indicating this brand should position itself also as imaginative and spirited.

Theoretically, this exploratory study illustrated the image congruence effect for online news brands, and showed that brand personality can serve as a point of strategic differentiation and a worthwhile unit of empirical observation. Looking at image congruence helps isolate brand personality factors related to attitudes and intentions, key indicators of individual behavioral tendencies toward a brand. While a brand has a particular perceived image or personality, self-brand congruity illustrates which personality traits (whether they are part of a brand's dominant personality or not) are most congruent with audience members' self-perceptions, facilitating a better understand of potential positioning strategies intended to enhance audience relations.

\subsection{Limitations and Future Research}

The main limitations of this study was that it relied on (1) a convenience sample of university students skewed toward females, not necessarily representative of all university students or the general population, and (2) self-report measures of attitudes and behavioral intentions. One should not generalize the results of this study beyond the group of students 
in the sample. Future research should use probability-sampling methods of other populations and more accurate measures of behaviors. Use of actual behavioral data, for example, viewing or usage data, would be a stronger dependent measure. In addition, other factors influence individual's brand attitudes and choice behaviors, each a function of its competitive product category. Future studies should isolate these factors and incorporate them, when applicable, into regression models to determine the predictive power of image congruence on overall online news brand attitudes.

A further study limitation was that brand personality scales may not have been the best technique for assessing self-brand congruence. While developed from measures used for human personality assessment, the BPS are intended for brand evaluation, and may not be the best technique for measuring respondent self-image. Other measures of self-image or actual personality likely would produce different results. Literature reports alternative measures of self-brand congruity, which applied in future research can help validate the present results. However, researchers have yet to develop a measure specifically for assessing self-brand personality congruity. Evidence here suggests this is a worthwhile topic to pursue.

Research also shows that self-brand congruity is not an important driver of consumer brand attitudes in all product categories, nor does it motivate behavior equally for all individuals (Dolich, 1969; Gould, 1991; Graff, 1986; Hogg et al., 2000; Sirgy, 1982). Two variables in particular, conspicuousness of brand use (i.e., private vs. publicly consumed), and consumers" "self-monitoring behavior" are evidenced to moderate the relationship between self-brand congruity and brand evaluations (Aaker, 1999; Gould, 1991; Landon, 1974; Zinkham \& Hong, 1991). The understanding of online news brand image and the congruence effect would benefit from research that evaluates these relationships. Furthermore, future studies that include factors used to evaluate news providers such as political orientation, speed and comprehensiveness of news delivery, and perceptions of impartiality would advance the understanding of self-brand congruity for online news brands.

\subsection{Conclusions}

Just as the brand Nike has a strong image (e.g., athletic and fashionable) that helps drive consumer choice and foster brand equity, news providers are brands that project unique images, and when well-managed, can elevate the overall product or service offering it represents. Rivals easily match brand strategies based merely on functional product or services aspects, leading to product parity in a category and dulling the competitive edge derived from a strong brand name. In addition to focusing on unique news content and programming, brand personality positioning, as an intricate part of an overall online news-brand identity strategy, is important to consider for establishing long-term differentiation and audience loyalty. Theories applied toward the study of commercial brands, such as self-congruity theory in the present study, facilitate the advancement of online news branding.

\section{References}

Aaker, D. A. (1996). Building strong brands. New York, NY: The Free Press.

Aaker, J. L. (1997). Dimensions of brand personality. Journal of Marketing Research, 34, $347-356$. http://dx.doi.org/10.2307/3151897

Aaker, J. L. (1999). The malleable self: The role of self-expression in persuasion. Journal of Marketing Research, 36 (1), 45-57. http://dx.doi.org/10.2307/3151914

Batra, R.., Myers, J. G., \& Aaker, D. A. (1996). Advertising management (5 ${ }^{\text {th }}$ ed.). Upper Saddle River, NJ: Prentice Hall.

Belk, R. W. (1988). Possessions and the extended self. Journal of Consumer Research, 15, 139-168.

Bellenger, D. N., Earl S., \& Stanton W. W. (1976). The congruence of store image and self-image. Journal of Retailing, 52 (Spring), 17-32.

Birdwell, A. E. (1968). A study of influence of image congruence on consumer choice. Journal of Business, $41,76-88$.

Chang, B., \& Chan-Olmsted, S. M. (2010). Success factors of cable network brand extension: Focusing on the parent network, composition, fit, consumer characteristics, and viewing habits. Journal of Broadcasting \& Electronic Media, 54(4), 641-656. http://dx.doi.org/10.1080/08838151.2010.519811

Chan-Olmsted, S. M., \& Jung, J. (2001). Strategizing the net business: How the U.S. television networks diversify, brand, and compete in the age of the Internet. International Journal on Media Management, 3(4), 213-225. http://dx.doi.org/10.1080/14241270109389970

Chan-Olmsted, S. M., \& Kim, Y. (2002). The PBS brand versus cable brands: Assessing the brand image of public television in a multichannel environment. Journal of Broadcasting and Electronic Media, 46(2), 300-320. 
Dacin, P. A., \& Smith, D. C. (1994). The effect of brand portfolio characteristics on consumer evaluations of brand extensions. Journal of Marketing Research, 31(2), 229-242. http://dx.doi.org/10.2307/3152196

Dolich, I. J. (1969). Congruence relationships between self-images and product brands. Journal of Marketing Research, 6, 80-84. http://dx.doi.org/10.2307/3150001

Erickson, M. K. (1996). Using self-congruity and ideal congruity to predict purchase intention: A European perspective. Journal of Euro-Marketing, 6, 41-56.

Fishbein, M., \& Ajzen, I. (1975). Belief, attitude, intention and behavior: An introduction to theory and research, Reading, MA: Addison-Wesley.

Franken, R. (1994). Human motivation ( ${ }^{\text {rd }}$ ed.), Pacific Grove, CA: Brooks/Cole.

Gould, S. J. (1991). The self-manipulation of my pervasive perceived vital energy through product use: An introspective-praxis perspective. Journal of Consumer Research, 18, (September), 194-207.

Graeff, T. R. (1996). Using promotional messages to manage the effects of brand and self-image on brand evaluations. Journal of Consumer Marketing, 13 (3), 4-18.

Grubb, E. L. \& Grathwhohl, H. L. (1967). Consumer self-concept, symbolism, and market behavior: A theoretical approach. Journal of Marketing, 31, 22-27. http://dx.doi.org/10.2307/1249461

Hair, J. F., Anderson, R. E., Tatham, R. L., \& Black, W.C. (1998). Multivariate data analysis. (5 ${ }^{\text {th }}$ ed.), Upper Saddle River, NJ: Prentice Hall.

Hogg, M. K., Alastair, J. C., \& Keeling, K. (2000). The impact of self-monitoring on image congruence and product/brand evaluation. European Journal of Marketing, 34, (5/6), 641.

Keller, K. L. (1993). Conceptualizing, measuring, and managing customer-based brand equity. Journal of Marketing, 57(1), 1-22. http://dx.doi.org/10.2307/1252054

Landers, D. E. (2004, August). Programming spin-offs as brand extensions: Capitalizing on the brand equity of network television hit series. Paper presented at the Association for Education in Journalism \& Mass Communication, Toronto, Canada. Abstract retrieved from http://www.aejmc.org/home/2012/page/34/

Landon, L. E. (1974). Self-concept, ideal self-concept, and consumer purchase intentions. Journal of Consumer Research, 1, 44-51.

MacKenzie, S. B., Lutz, R. J., \& Park, W.P. (1989). An empirical examination of the structural antecedents of attitude toward the ad in an advertising pretesting context. Journal of Marketing, 53, 48-65. http://dx.doi.org/10.2307/1251413

Malhotra, N. K. (1981). A scale to measure self-concepts, person concepts and product concepts. Journal of Marketing Research, 23, (November), 456-64. http://dx.doi.org/10.2307/3151339

McCraken, G. S. (1986). Culture and consumption: A theoretical account of the structure and movement of cultural meaning of consumer goods. Journal of Consumer Research, 13(June), 71-84.

McDowell, W. S. (1998), Conceptualizing and measuring the effects of brand equity on television program ratings performance. (Unpublished doctoral dissertation), University of Florida, Gainesville, Florida, United States.

Mitchell, A. A., \& Olson, J. C. (1981). Are product beliefs the only mediator of advertising effect on brand attitudes? Journal of Marketing Research, 18 (August), 318-32. http://dx.doi.org/10.2307/3150973

Park, C. W., Jaworski, B. J., \& Macinnis, D. J. (1986). Strategic brand concept-image Management. Journal of Marketing, 50 (October), 135-146. http://dx.doi.org/10.2307/1251291

Patterson, M. (1999). Re-appraising the concept of brand image. Journal of Brand Management, 6, 409-426. http://dx.doi.org/10.1057/bm.1999.32

Phau, I., \& Lau, K.C. (2001). Brand personality and consumer self-expression: Single or dual carriageway? Journal of Brand Management, 8, 428-444. http://dx.doi.org/10.1057/palgrave.bm.2540042

Plummer, J. T. (2000). How personality makes a difference. Journal of Advertising Research. Nov-Dec, 79-82.

Rogers, C. R. (1959). A theory of therapy, personality, and interpersonal relationships, as developed in the client-centered framework. In S. Koch (ed.), Psychology: A study of a science 3, 184-256. New York, NY: McGraw-Hill.

Ross, I. (1971). Self-concept and brand preference. Journal of Business of the University of Chicago, 44, 38-50. 
Sirgy, M. J. (1982). Self-Concept in consumer behavior: A critical review. Journal of Consumer Research, 9, 87-300.

Sirgy, M. J. (1986). Self-congruity: Toward a theory of personality and Cybernetics. New York, NY: Praeger Publishers.

Solomon, M. R. (1983). The role of products in social stimuli: A symbolic interactionism perspective. Journal of Consumer Behavior, 10, 319-329.

Spears, N., \& Singh, S. (2004). Measuring attitude toward the brand and purchase intentions. Journal of Current Issues and Research in Advertising, 26 (2), 53-66.

Underwood, R., Bond, E., \& Baer, R. (2001). Building service brands via social identity: Lessons from the sports marketplace. Journal of Marketing Theory and Practice, 9(1), 1-12.

Ziegler, J. D., \& Hjelle, L. A. (1992). Personality theories: Basic assumptions, research, and Applications. New York, NY: McGraw-Hill Co.

Zinkham, G. M., \& Hong, J. W. (1991). Self-concept and advertising effectiveness: A conceptual model of congruency, conspicuousness, and response mode. Advances in Consumer Research, 18, 348-354.

\section{(c) $\overline{E Y}$}

This work is licensed under a Creative Commons Attribution 3.0 License. 